\title{
Synthesis, structural characterization and biological activities of organotin(IV) complexes with 5-allyl-2-hydroxy-3- methoxybenzaldehyde-4-thiosemicarbazone
}

\author{
ROSENANI A HAQUE and M A SALAM* \\ The School of Chemical Sciences, Universiti Sains Malaysia, 11800 USM, Penang, Malaysia \\ e-mail: rosenani@usm.my; salambpx@yahoo.com
}

MS received 15 April 2015; revised 14 June 2015; accepted 18 June 2015

\begin{abstract}
The organotin(IV) complexes [MeSnCl(L)] (2), [BuSnCl(L)] (3), [PhSnCl(L)] (4) and [ $\left.\mathrm{Me}_{2} \mathrm{Sn}(\mathrm{L})\right]$ (5) were synthesized by reacting organotin(IV) chloride(s) with 5-allyl-2-hydroxy-3-methoxybenzaldehyde4-thiosemicarbazone $\left.\left[\mathrm{H}_{2} \mathrm{~L}\right],(\mathbf{1})\right]$ in presence of $\mathrm{KOH}$ in 1:2:1 molar ratio (metal salt: base:ligand). All the complexes have been characterized by elemental analyses, UV-Vis, FT-IR, ${ }^{1} \mathrm{H},{ }^{13} \mathrm{C}$ and ${ }^{119} \mathrm{Sn}$ NMR spectral studies. The molecular structure of complex $\mathbf{5}$ has been confirmed by single crystal X-ray diffraction analysis. The ligand, $\mathrm{H}_{2} \mathrm{~L}$ coordinates to $\mathrm{Sn}(\mathrm{IV})$ in thiolate form through phenoxide- $\mathrm{O}$, azomethine- $\mathrm{N}$ and thiolate-S atoms. The C-Sn-C angle measured from coupling constant ${ }^{1} J\left({ }^{119} \mathrm{Sn},{ }^{13} \mathrm{C}\right)$ for dimethyltin(IV) complex $\mathbf{5}$ is $123.4^{\circ}$. The ${ }^{2} J\left({ }^{119} \mathrm{Sn},{ }^{1} \mathrm{H}\right)$ coupling constant values for complex 2 and $\mathbf{5}$ are 72.4 and $76.3 \mathrm{~Hz}$, respectively. Proposed geometry for five coordinated Sn(IV) atom is a strongly distorted trigonal bipyramid. Biological studies were preformed in vitro against four bacterial strains which have shown better activities and potential as antibacterial agents.
\end{abstract}

Keywords. 4-thiosemicarbazone; Organotin(IV) complexes; synthesis; characterization; crystal structure; antibacterial activity.

\section{Introduction}

Thiosemicarbazones have been the subject of interest due to their medicinal and biological applications as antioxidant, DNA binding, anti-proliferative, antimalarial, antitumor and antibacterial agents. ${ }^{1-6}$ Generally, the biological activity of thiosemicarbazones is influenced significantly upon coordination to metal ions. ${ }^{7,8}$ Organotin(IV) complexes with ligands containing ON, OS, ONS and NNS donors are notable for their wonderful biological activities as fungicides, bacteriocides and anti-inflammatory agents. ${ }^{9,10}$ Tin complexes are also established for their various biological applications as antibacterial, antifungal, biocidal and cytotoxic agents. ${ }^{11-13}$ Mostly, biological activity of metal-thiosemicarbazones is influenced by the metal coordination number and structure of the molecule. ${ }^{14-16}$ In particular, complexes with thiosemicarbazones derived from ONS dianionic tridentate ligand have been extensively reported. ${ }^{17-19}$ Sousa et al., have reported structural studies of organotin(IV) complex with ONS-tridentate thiosemicarbazone and X-ray

\footnotetext{
*For correspondence
}

structure revealed that tin atom is penta-coordinated in a distorted trigonal bipyramidal geometry. ${ }^{20}$ Recently, Mouyed et al., have reported synthesis and structural studies of molybdenum(VI) complexes with ONS-donors thiosemicarbazone ligands. These complexes have been shown to exhibit significant antitumour activities. ${ }^{21,22}$ Coordination of certain metal complexex with thiosemicarbazone derivatives have been studied along with a structural review of the main group metal complexes with thiosemicarbazoenes. ${ }^{23-25}$ However, most of the work that have been reported still involves complexes of thiosemicarbazones with transition metal ions. Though organotin(IV) complexes with thiosemicarbazone derivatives have potential biological activities, ${ }^{26-28}$ very few reports are available regarding the mode of interaction between organotin(IV) moieties and ONS tridentate thiosemicarbazone ligands and the nature of these complexes in solution and solid state. In the present work, we report the synthesis spectroscopic characterization and antibacterial activity of new organotin(IV) complexes of 5-allyl-2-hydroxy-3-methoxybenzaldehyde4-thiosemicarbazone. X-ray crystal structure of one representative complex is also reported. 


\section{Experimental}

\subsection{Materials and methods}

All reagents were purchased from Fluka, Sigma and Aldrich. All solvents were received as reagent grade and used without further purification. Melting point was measured on Stuart Scientific SMP1 melting point apparatus. UV-Vis spectra were recorded in DMSO with a Perkin Elmer Lambda 25 UV-Vis spectrophotometer. FT-IR spectra were recorded on a Perkin Elmer System 2000 spectrophotometer in $\mathrm{KBr}$ pellet in the $4000-400 \mathrm{~cm}^{-1}$ range at room temperature. ${ }^{1} \mathrm{H},{ }^{13} \mathrm{C}$ and ${ }^{119} \mathrm{Sn}$ NMR spectra were recorded on a Bruker 500 and $400 \mathrm{MHz}$ NMR spectrophotometer and $\delta$ is relative to $\mathrm{SiMe}_{4}$ and $\mathrm{SnMe}_{4}$ in DMSO- $d_{6}$. Elemental analysis was conducted with a Perkin Elmer 2400 Series-11 CHN analyzer. X-ray crystallographic data were recorded on a Bruker SMART APEXII CCD area-detector diffractometer using graphite monochromated $\mathrm{MoK} \alpha$ radiation $(\lambda=0.71073 \AA)$ at $100 \mathrm{~K}$. The data were collected and reduced using APEX2 and SAINT programs. The structures were solved by direct methods and refined by full-matrix least-squares method on $F^{2}$ using the SHELXTL program. ${ }^{29}$ All non-H atoms were anisotropically refined. The molecular graphics were created using SHELXTL-97.

\subsection{Synthesis of 5-allyl-2-hydroxy-3-methoxybenzal- dehyde-4-thiosemicarbazone $\left(\mathrm{H}_{2} \mathrm{~L}\right)(\mathbf{1})$}

A solution of 5-allyl-3-methoxy-2-hydroxybenzaldehyde $(0.57 \mathrm{~g}, 3.0 \mathrm{mmol})$ in $10 \mathrm{~mL}$ absolute ethanol was treated with $10 \mathrm{~mL}$ absolute ethanolic solution of thiosemicarbazide $(0.27 \mathrm{~g}, 3.0 \mathrm{mmol})$. The resulting colorless solution was refluxed with stirring for $4 \mathrm{~h}$ (scheme 1). White solid product was formed when the solution cooled down to room temperature, then filtered, washed with ethanol and dried in desiccators over silica gel. Yield: 0.68 g, $80 \%$ : M.p.: $189-191^{\circ} \mathrm{C}$ : UV-Vis (DMSO) $\lambda_{\max } / \mathrm{nm}$ : 260,328 , 366: FT-IR (KBr) $v_{\max } / \mathrm{cm}^{-1}: 3411(\mathrm{~s}, \mathrm{OH}), 3335\left(\mathrm{~s}, \mathrm{NH}_{2}\right), 3185(\mathrm{~s}, \mathrm{NH})$, $1620(\mathrm{~m}, \mathrm{C}=\mathrm{N}), 1562\left(\mathrm{~s}, \mathrm{C}_{\text {aro }}-\mathrm{O}\right), 998(\mathrm{~m}, \mathrm{~N}-\mathrm{N}), 1363$, 859 (w, CS). ${ }^{1} \mathrm{H}$ NMR (DMSO- $\left.d_{6}, \mathrm{ppm}\right): 11.40(\mathrm{~s}, 1 \mathrm{H}$, $\mathrm{OH}), 10.14(\mathrm{~s}, 1 \mathrm{H}, \mathrm{NH}), 9.13\left(\mathrm{~s}, 2 \mathrm{H}, \mathrm{NH}_{2}\right), 8.28$ (s, $1 \mathrm{H}, \mathrm{N}=\mathrm{CH}), 7.34$ (s, 1H, PhC4-H), 7.10 (s, 1H, PhC6$\mathrm{H}), 5.98\left(\mathrm{~m}, 1 \mathrm{H}, \mathrm{CH}_{2}=\mathrm{CH}-\mathrm{CH}_{2}-\mathrm{Ph}\right), 5.02(\mathrm{~m}, 2 \mathrm{H}$, $\left.\mathrm{CH}_{2}=\mathrm{CH}-\mathrm{CH}_{2}-\mathrm{Ph}\right), 3.76\left(\mathrm{~d}, 2 \mathrm{H}, \mathrm{CH}_{2}=\mathrm{CH}-\mathrm{CH}_{2}-\mathrm{Ph}\right.$, $J=6.5 \mathrm{~Hz}), 3.28\left(\mathrm{~s}, 3 \mathrm{H}, \mathrm{OCH}_{3}\right) .{ }^{13} \mathrm{C}$ NMR (DMSO$\left.d_{6}, \mathrm{ppm}\right): 191.23(\mathrm{C}=\mathrm{S}), 152.81(\mathrm{C}=\mathrm{N}), 136.14-120.28$ $(\mathrm{Ph}-\mathrm{C}), 117.40(=\mathrm{CH}), 115.47\left(\mathrm{CH}_{2}=\right), 113.19\left(\mathrm{CH}_{2}-\right.$ $\mathrm{Ph}), 55.79\left(\mathrm{O}-\mathrm{CH}_{3}\right)$. Anal. Calc. (\%) for $\mathrm{C}_{12} \mathrm{H}_{15} \mathrm{~N}_{3} \mathrm{O}_{2} \mathrm{~S}$ : C, 54.32; H, 5.70; N, 15.84. Found: C, 54.35; H, 5.52; N, 16.01.

\subsection{Synthesis of $[\mathrm{MeSnCl}(L)](2)$}

The ligand, $\mathrm{H}_{2} \mathrm{~L}$ (1) $(0.265 \mathrm{~g}, 1.0 \mathrm{mmol})$ was dissolved in absolute methanol $(10 \mathrm{~mL})$ under a nitrogen atmosphere in a round-bottomed reaction flask. Potassium hydroxide $(0.11 \mathrm{~g}, 2.0 \mathrm{mmol})$ in methanol $(10 \mathrm{~mL})$ was added dropwise to the ligand solution. The reaction mixture was refluxed for $1 \mathrm{~h}$. Then, a methanolic solution of methyltin(IV) trichloride $(0.24 \mathrm{~g}, 1.0 \mathrm{mmol})$ was added dropwise and resulted in a yellow solution. The resulting reaction mixture was refluxed with stirring for $4 \mathrm{~h}$ (scheme 2). The yellow solid product was obtained by slow evaporation of the resulting solution at room temperature. The yellow product was filtered off, washed with methanol, and dried in vacuo over silica gel. Yield: $0.38 \mathrm{~g}, 75 \%$ : M.p.: $232-234^{\circ} \mathrm{C}$. UVVis (DMSO) $\lambda_{\max } / \mathrm{nm}: 272,337,380,429$ : FT-IR (KBr) $v_{\max } / \mathrm{cm}^{-1}: 3285\left(\mathrm{~s}, \mathrm{NH}_{2}\right), 1587(\mathrm{~m}, \mathrm{C}=\mathrm{N}), 1531(\mathrm{~s}$,<smiles>C=CC=Cc1cc(CC=CC=CC(=O)N/N=C/c2cc(CC=C)cc(/C=N/NC(N)=S)c2O)c(O)c(OC)c1</smiles>

Scheme 1. Synthesis of 5-allyl-2-hydroxy-3-methoxybenzaldehyde-4-thiosemicarbazone $\left[\mathrm{H}_{2} \mathrm{~L}, \mathbf{1}\right]$. 


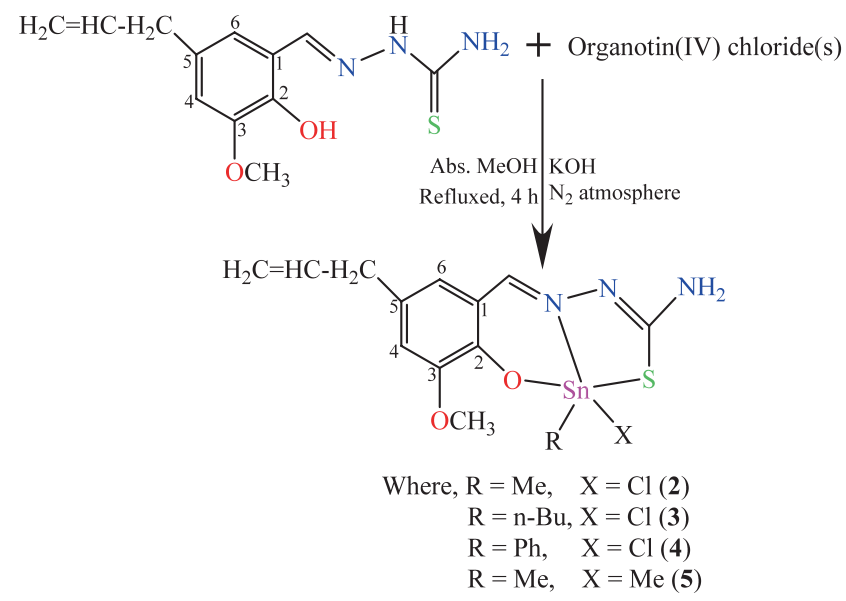

Scheme 2. Reaction scheme for synthesis of organotin(IV) complexes (2-5).

$\left.\mathrm{C}_{\text {aro }}-\mathrm{O}\right), 1020$ (w, N-N), 1329, 830 (m, C-S), 582 (w, SnC), 541 (w, Sn-O), 450 (w, Sn-N). ${ }^{1} \mathrm{H}$ NMR (DMSO$\left.d_{6}, \mathrm{ppm}\right): 9.08\left(\mathrm{~s}, 2 \mathrm{H}, \mathrm{NH}_{2}\right), 8.17(\mathrm{~s}, 1 \mathrm{H}, \mathrm{N}=\mathrm{CH}), 7.38$ (s, 1H, PhC4-H), 7.14 (s, 1H, PhC6-H), 5.95 (m, 1H, $\left.\mathrm{CH}_{2}=\mathrm{CH}-\mathrm{CH}_{2}-\mathrm{Ph}\right), 5.05\left(\mathrm{~m}, 2 \mathrm{H}, \mathrm{CH}_{2}=\mathrm{CH}-\mathrm{CH}_{2}-\mathrm{Ph}\right)$, $3.70\left(\mathrm{~d}, 2 \mathrm{H}, \mathrm{CH}_{2}=\mathrm{CH}-\mathrm{CH}_{2}-\mathrm{Ph}, J=6.8 \mathrm{~Hz}\right), 3.25(\mathrm{~s}$, $\left.3 \mathrm{H}, \mathrm{OCH}_{3}\right), 1.07\left(\mathrm{~s}, 3 \mathrm{H},{ }^{2} \mathrm{~J}_{\mathrm{Sn}-\mathrm{H}}=72.4 \mathrm{~Hz}, \mathrm{Sn}-\mathrm{CH}_{3}\right)$. ${ }^{13} \mathrm{C}$ NMR (DMSO- $\left.d_{6}, \mathrm{ppm}\right): 182.11(\mathrm{C}=\mathrm{S}), 161.75$ $(\mathrm{C}=\mathrm{N}), 142.32-125.62(\mathrm{Ph}-\mathrm{C}), 117.45(=\mathrm{CH}), 115.50$ $\left(\mathrm{CH}_{2}=\right), 113.25\left(\mathrm{CH}_{2}-\mathrm{Ph}\right), 55.75\left(\mathrm{O}-\mathrm{CH}_{3}\right), 18.31$ $\left({ }^{1} \mathrm{~J}_{\mathrm{Sn}-\mathrm{C}}=531.82 \mathrm{~Hz}, \mathrm{Sn}-\mathrm{CH}_{3}\right) .{ }^{119} \mathrm{Sn}$ NMR (DMSO- $d_{6}$, ppm): -154.48. Anal. Calc. (\%) for $\mathrm{C}_{13} \mathrm{H}_{16} \mathrm{ClN}_{3} \mathrm{O}_{2} \mathrm{SSn}$ : C, 36.10; H, 3.73; N, 9.72. Found: C, 36.26; H, 3.86; N, $9.87 \%$.

Other organotin(IV) complexes (3-5) were synthesised following the same procedure by using the appropriate organotin(IV) chloride(s) (scheme 2).

\subsection{Synthesis of $[\mathrm{BuSnCl}(L)](3)$}

Yield: $\quad 0.40 \mathrm{~g}, \quad 73 \%$ : M.p: $\quad 240-242^{\circ} \mathrm{C} . \quad \mathrm{UV}-\mathrm{Vis}$ (DMSO) $\lambda_{\max } / \mathrm{nm}: 270,339,387$, 442: FT-IR $(\mathrm{KBr})$ $v_{\max } / \mathrm{cm}^{-1}: 3291\left(\mathrm{~s}, \mathrm{NH}_{2}\right), 1590(\mathrm{~m}, \mathrm{C}=\mathrm{N}), 1527(\mathrm{~s}$, $\mathrm{C}_{\text {aro }}-\mathrm{O}$ ), 1018 (w, N-N), 1330, 834 (m, C-S), 578 (w, Sn-C), 549 (w, Sn-O), 432 (w, Sn-N). ${ }^{1} \mathrm{H}$ NMR (DMSO- $\left.d_{6}, \mathrm{ppm}\right): 9.05\left(\mathrm{~s}, 2 \mathrm{H}, \mathrm{NH}_{2}\right), 8.25(\mathrm{~s}, 1 \mathrm{H}$, $\mathrm{N}=\mathrm{CH}), 7.39$ (s, 1H, PhC4-H), 7.15 (s, 1H, PhC6$\mathrm{H}), 5.93\left(\mathrm{~m}, 1 \mathrm{H}, \mathrm{CH}_{2}=\mathrm{CH}-\mathrm{CH}_{2}-\mathrm{Ph}\right), 5.10(\mathrm{~m}, 2 \mathrm{H}$, $\left.\mathrm{CH}_{2}=\mathrm{CH}-\mathrm{CH}_{2}-\mathrm{Ph}\right), 3.72\left(\mathrm{~d}, 2 \mathrm{H}, \mathrm{CH}_{2}=\mathrm{CH}-\mathrm{CH}_{2}-\mathrm{Ph}\right.$, $J=6.7 \mathrm{~Hz}), 3.23\left(\mathrm{~s}, 3 \mathrm{H}, \mathrm{OCH}_{3}\right), 1.61-1.55(\mathrm{t}, 2 \mathrm{H}, \mathrm{Sn}-$ $\underline{\mathrm{CH}_{2}}-\mathrm{CH}_{2}-\mathrm{CH}_{2}-\mathrm{CH}_{3}$ ), 1.40-1.34 (m, 2H Sn- $\mathrm{CH}_{2}-\mathrm{CH}_{2}-$ $\left.\mathrm{CH}_{2}-\mathrm{CH}_{3}\right), 1.21-1.15$ (m, 2H, Sn- $\mathrm{CH}_{2}-\mathrm{CH}_{2}-\mathrm{CH}_{2}-\mathrm{CH}_{3}$ ), 0.94-0.85 (t, 3H, Sn- $\left.\mathrm{CH}_{2}-\mathrm{CH}_{2}-\mathrm{CH}_{2}-\mathrm{CH}_{3}\right),{ }^{13} \mathrm{C} \mathrm{NMR}$ $\left(\mathrm{DMSO}-d_{6}, \mathrm{ppm}\right): 177.25 \quad(\mathrm{C}=\mathrm{S}), 165.82 \quad(\mathrm{C}=\mathrm{N})$, 140.02-124.21 (Ph-C), $117.42(=\mathrm{CH}), 115.40\left(\mathrm{CH}_{2}=\right)$, $113.20\left(\mathrm{CH}_{2}-\mathrm{Ph}\right), 55.82\left(\mathrm{O}-\mathrm{CH}_{3}\right), 38.01,32.32,26.81$, $22.65(\mathrm{Sn}-\mathrm{Bu}) .{ }^{119} \mathrm{Sn}$ NMR (DMSO- $\left.d_{6}, \mathrm{ppm}\right):-162.37$.
Anal. Calc. (\%) for $\mathrm{C}_{16} \mathrm{H}_{22} \mathrm{ClN}_{3} \mathrm{O}_{2} \mathrm{SSn}$ : C, 40.49; H, 4.67 ; N, 8.85. Found: C, 40.76; H, 4.77; N, 8.99\%.

\subsection{Synthesis of $[\mathrm{PhSnCl}(L)](4)$}

Yield: $\quad 0.41 \mathrm{~g}, \quad 72 \%$ : M.p: $246-248^{\circ} \mathrm{C} . \quad \mathrm{UV}-\mathrm{Vis}$ (DMSO) $\lambda_{\max } / \mathrm{nm}: 274,344,382$, 422: FT-IR (KBr) $v_{\max } / \mathrm{cm}^{-1}: 3288\left(\mathrm{~s}, \mathrm{NH}_{2}\right), 1588(\mathrm{~m}, \mathrm{C}=\mathrm{N}), 1522$ (s, $\left.\mathrm{C}_{\text {aro }}-\mathrm{O}\right), 1026$ (w, N-N), 1335, 840 (m, C-S), 588 (w, Sn-C), 561 (w, Sn-O), 443 (w, Sn-N). ${ }^{1} \mathrm{H}$ NMR (DMSO- $\left.d_{6}, \mathrm{ppm}\right): 9.10\left(\mathrm{~s}, 2 \mathrm{H}, \mathrm{NH}_{2}\right), 8.23$ (s, $1 \mathrm{H}$, $\mathrm{N}=\mathrm{CH}), 7.40-7.12(\mathrm{~m}, 7 \mathrm{H}, \mathrm{Ph}-\mathrm{H}), 5.90(\mathrm{~m}, 1 \mathrm{H}$, $\left.\mathrm{CH}_{2}=\mathrm{CH}-\mathrm{CH}_{2}-\mathrm{Ph}\right), 5.03\left(\mathrm{~m}, 2 \mathrm{H}, \underline{\mathrm{CH}}_{2}=\mathrm{CH}-\mathrm{CH}_{2}-\mathrm{Ph}\right)$, $3.78\left(\mathrm{~d}, 2 \mathrm{H}, \mathrm{CH}_{2}=\mathrm{CH}-\mathrm{CH}_{2}-\mathrm{Ph}, J=6.6 \mathrm{~Hz}\right), 3.27$ $\left(\mathrm{s}, 3 \mathrm{H}, \mathrm{OCH}_{3}\right) \cdot{ }^{13} \mathrm{C}$ NMR (DMSO- $\left.d_{6}, \mathrm{ppm}\right): 179.72$ $(\mathrm{C}=\mathrm{S}), 162.33(\mathrm{C}=\mathrm{N}), 141.22-126.40(\mathrm{Ph}-\mathrm{C}), 117.32$ $(=\mathrm{CH}), 114.98\left(\mathrm{CH}_{2}=\right), 113.35\left(\mathrm{CH}_{2}-\mathrm{Ph}\right), 55.85(\mathrm{O}-$ $\left.\mathrm{CH}_{3}\right) .{ }^{119} \mathrm{Sn}$ NMR (DMSO- $\left.d_{6}, \mathrm{ppm}\right):-167.02$. Anal. Calc. (\%) for $\mathrm{C}_{18} \mathrm{H}_{18} \mathrm{ClN}_{3} \mathrm{O}_{2} \mathrm{SSn}: \mathrm{C}, 43.71 ; \mathrm{H}, 3.67 ; \mathrm{N}$, 8.50. Found: C, $43.88 ; \mathrm{H}, 3.80 ; \mathrm{N}, 8.65 \%$.

\subsection{Synthesis of $\left[\mathrm{Me}_{2} \operatorname{Sn}(L)\right](5)$}

Yield: $\quad 0.36 \mathrm{~g}, \quad 74 \%$ : M.p: $235-237^{\circ} \mathrm{C}$. UV-Vis (DMSO) $\lambda_{\max } / \mathrm{nm}: 271,340,377,418:$ FT-IR (KBr) $v_{\max } / \mathrm{cm}^{-1}: 3293\left(\mathrm{~s}, \mathrm{NH}_{2}\right), 1582(\mathrm{~m}, \mathrm{C}=\mathrm{N}), 1524(\mathrm{~s}$, $\left.\mathrm{C}_{\text {aro }}-\mathrm{O}\right), 1030$ (w, N-N), 1321, 842 (m, C-S), 591 (w, Sn-C), 550 (w, Sn-O), 462 (w, Sn-N). ${ }^{1} \mathrm{H}$ NMR (DMSO- $\left.d_{6}, \mathrm{ppm}\right): 9.04\left(\mathrm{~s}, 2 \mathrm{H}, \mathrm{NH}_{2}\right), 8.08(\mathrm{~s}, 1 \mathrm{H}$, $\mathrm{N}=\mathrm{CH}), 7.41(\mathrm{~s}, 1 \mathrm{H}, \mathrm{PhC} 4-\mathrm{H}), 7.21(\mathrm{~s}, 1 \mathrm{H}, \mathrm{PhC6}-$ $\mathrm{H}), 5.99\left(\mathrm{~m}, 1 \mathrm{H}, \mathrm{CH}_{2}=\mathrm{CH}-\mathrm{CH}_{2}-\mathrm{Ph}\right), 5.08(\mathrm{~m}, 2 \mathrm{H}$, $\left.\underline{\mathrm{CH}_{2}}=\mathrm{CH}-\mathrm{CH}_{2}-\mathrm{Ph}\right), 3.79\left(\mathrm{~d}, 2 \mathrm{H}, \mathrm{CH}_{2}=\mathrm{CH}-\underline{\mathrm{CH}}_{2}-\right.$ $\mathrm{Ph}, J=6.4 \mathrm{~Hz}), 3.30\left(\mathrm{~s}, 3 \mathrm{H}, \mathrm{OCH}_{3}\right), 1.10(\mathrm{~m}, 6 \mathrm{H}$, $\left.{ }^{2} \mathrm{~J}_{\mathrm{Sn}-\mathrm{H}}=76.3 \mathrm{~Hz}, \mathrm{Sn}-\left(\mathrm{CH}_{3}\right)_{2}\right) \cdot{ }^{13} \mathrm{C}$ NMR (DMSO- $d_{6}$, ppm): $178.35(\mathrm{C}=\mathrm{S}), 168.72(\mathrm{C}=\mathrm{N}), 140.26-133.38$ (Ph-C), $118.55(=\mathrm{CH}), 116.11\left(\mathrm{CH}_{2}=\right), 112.24\left(\mathrm{CH}_{2^{-}}\right.$

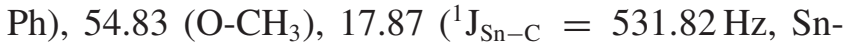
$\left.\left(\mathrm{CH}_{3}\right)_{2}\right) .{ }^{119} \mathrm{Sn}$ NMR (DMSO- $\left.d_{6}, \mathrm{ppm}\right):-171.35$. Anal. 
Calc. (\%) for $\mathrm{C}_{14} \mathrm{H}_{19} \mathrm{~N}_{3} \mathrm{O}_{2} \mathrm{SSn}: \mathrm{C}, 40.80 ; \mathrm{H}, 4.65 ; \mathrm{N}$, 10.20. Found: C, 40.93; H, 4.72; N, 10.33\%.

\subsection{Antibacterial test}

The synthesized compounds $\mathbf{1 - 5}$ were screened in vitro antibacterial activities against Staphylococcus aureus (ATCC 6538), Enterobacter aerogenes (ATCC 13048), Escherichia colii (ATCC 15224) and Salmonella typhi (ATCC 10749) using the agar well diffusion method. ${ }^{30}$ Doxycycline was used as the standard drug. The bacteria from stock culture were lightly inoculated into the Mueller Hinton Broth (MHB) and allowed to grow overnight at $37^{\circ} \mathrm{C}$ in an ambient air incubator. The culture was diluted with a new MHB in order to achieve an absorbance value of $2.0 \times 10^{6}$ colony forming units $(\mathrm{CFU} / \mathrm{mL})$ or 0.168 at $550 \mathrm{~nm}$ in the spectrophotometer. Sterile cotton swab was dipped into the broth culture and inoculated on the Mueller Hinton Agar (MHA). Sterile paper discs with $6 \mathrm{~mm}$ diameter were placed on the agar in equal distance. The recommended concentration of the test sample $(2 \mathrm{mg} / \mathrm{mL}$ in DMSO) was introduced individually to each of the discs. The agar plates were incubated immediately at $37^{\circ} \mathrm{C}$ for $20 \mathrm{~h}$. For each plate, DMSO mixture and reference antibacterial drug such as doxycycline served as negative and positive controls, respectively. The activity was determined by measuring the diameter of zones showing complete inhibition (mm). Growth inhibition was calculated with reference to the positive control.

\section{Results and Discussion}

\subsection{Synthesis}

The ligand, 5-allyl-2-hydroxy-3-methoxybenzaldehyde4-thiosemicarbazone $\left(\mathrm{H}_{2} \mathrm{~L}\right)$ was prepared by reaction of 5-allyl-2-hydroxy-3-methoxybenzaldehyde with thiosemicarbazide. It exhibits two possible tautomers either as thione or thiol forms (scheme 1). $\mathrm{H}_{2} \mathrm{~L}$ was treated with corresponding organotin(IV) chloride(s) in presence of $\mathrm{KOH}$ to obtain organotin(IV) derivatives (scheme 2). The obtained organotin(IV) compounds are yellow solids stable in air and soluble in methanol, chloroform, THF, DMSO and DMF. Elemental analysis data confirms that the complexes are of good purity. The physical and analytical data are reported in experimental section. The nature of bonding and structures of ligand and its complexes were suggested by spectroscopic studies. The molecular structure of complex $\mathbf{5}$ is also reported.

\subsection{UV-Visible spectra}

The electronic spectrum of ligand (1) has $\pi-\pi^{*}$ band at $260 \mathrm{~nm}$ and two $\mathrm{n}-\pi^{*}$ bands around in the region at $328-366 \mathrm{~nm}$ due to the transitions of aromatic ring, thiolate function and azomethine group, respectively. These bands are slightly shifted in energy after complexation. In all the complexes, a moderately intense band was observed in the region at $442-418 \mathrm{~nm}$ assigned to ligand-to-metal-charge-transfer transitions (LMCT). ${ }^{31}$ The shift of $\lambda_{\max }$ clearly indicates the coordination of the ligand to metal. The UV-Vis spectra of organotin(IV) complexes (4-5) and the ligand are shown in figure 1 .

\subsection{Infrared spectra}

IR spectra clarify the mode of the ligand bonded to the tin moiety and support their proposed structures. The free ligand (1) exhibit $v(\mathrm{OH})$ stretching vibrations at $3411 \mathrm{~cm}^{-1}$ which was absent in the spectra of the complexes (2-5), indicating deprotonation of phenolic proton and bond formation with $\mathrm{Sn}(\mathrm{IV})$ atom. The $v(\mathrm{NH})$ stretching vibration of free ligand was observed at $3185 \mathrm{~cm}^{-1}$. This band disappeared in the IR spectra of the complexes (2-5), which is attributed to the coordination bond of azomethine nitrogen to $\mathrm{Sn}(\mathrm{V})$ atom. The absence of $v(\mathrm{~S}-\mathrm{H})$ peak around $2700 \mathrm{~cm}^{-1}$ in the spectrum of free ligand (1) indicates that ligand is in thione form in the solid state. ${ }^{32,33}$ The $v(\mathrm{C}=\mathrm{N})$ band which observed at $1620 \mathrm{~cm}^{-1}$ in IR spectrum of free ligand shifted to lower frequencies in the complexes, in agreement with coordination of azomethine nitrogen to $\mathrm{Sn}(\mathrm{IV})$ atom. ${ }^{34}$ The $v(\mathrm{~N}-\mathrm{N})$ band in free ligand at $998 \mathrm{~cm}^{-1}$ is shifted to higher wave numbers at $1030-1018 \mathrm{~cm}^{-1}$ in the complexes, indicating that the azomethine nitrogen atom is involved in coordination. The $v(\mathrm{C}-\mathrm{S})$ stretching and bending vibrations observed at 1363 and $859 \mathrm{~cm}^{-1}$ in the free ligand is shifted to lower wave numbers at $1335-1321$ and $842-830 \mathrm{~cm}^{-1}$ in the complexes, indicating bonding of thiolate sulphur to $\mathrm{Sn}(\mathrm{IV})$ atom. ${ }^{35}$ Absorption band of $v\left(\mathrm{C}_{\text {aro }}-\mathrm{O}\right)$ in free ligand appeared at $1562 \mathrm{~cm}^{-1}$ is shifted to

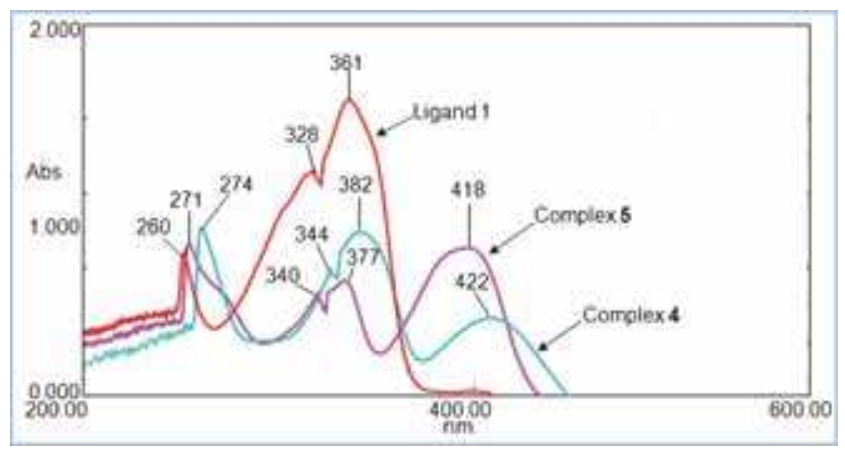

Figure 1. UV-Vis spectra of ligand (1) and its complexes $(4$ and 5$)$ in DMSO $\left(1 \times 10^{-4} \mathrm{M}\right)$. 
lower wave numbers at $1531-1522 \mathrm{~cm}^{-1}$ in the complexes, suggesting the involvement of phenolic oxygen in coordination. ${ }^{36}$ New bands in the region at 561-541 and $462-422 \mathrm{~cm}^{-1}$ are assigned to $v(\mathrm{Sn}-\mathrm{O})$ and $v(\mathrm{Sn}-$ $\mathrm{N})$, respectively, supporting coordination of oxygen and nitrogen to $\mathrm{Sn}$ (IV) atom. ${ }^{37-39}$ The weak band assigned to $v(\mathrm{Sn}-\mathrm{C})$ observed at $591-578 \mathrm{~cm}^{-1}$ which confirms that $\mathrm{Sn}-\mathrm{C}$ bond in their structure. ${ }^{40}$ The IR spectral data suggested that thiosemicarbazone ligand $\left(\mathrm{H}_{2} \mathrm{~L}\right)$ act as dinegative ONS tridentate chelating agent coordinated to central tin(IV) atom through phenolic oxygen, azomethine nitrogen and thiolate sulphur atoms. This mode of coordination has been confirmed by the X-ray structure studies of dimethyltin(IV) complex $\mathbf{5}$.

\section{$3.4{ }^{1} \mathrm{H},{ }^{13} \mathrm{C}$ and ${ }^{119} \mathrm{Sn}$ NMR spectra}

The ${ }^{1} \mathrm{H}$ and ${ }^{13} \mathrm{C}$ spectra of ligand (1) and its complexes (2-5) and of the ${ }^{119} \mathrm{Sn}$ NMR spectra of the complexes (2-5) were recorded in DMSO. The free ligand displayed signal at $11.40 \mathrm{ppm}$ is attributed to $\mathrm{OH}$ proton and the sharp signal at $10.14 \mathrm{ppm}$ is assigned to $\mathrm{NH}$ proton. The absence of these two signals upon complexation indicating deprotonation of these groups and coordinated with tin(IV) atom. The appearance of a sharp resonance peak at $9.10-9.04 \mathrm{ppm}$ is due to the $\mathrm{NH}_{2}$ group in all complexes. The chemical shifts of $\mathrm{N}=\mathrm{CH}$ proton for ligand appears at $8.28 \mathrm{ppm}$ which is shifted upfield region at $8.25-8.08 \mathrm{ppm}$ due to complex formation. The resonance signals due to aromatic $4-\mathrm{H}$ and $6-\mathrm{H}$ protons were found to be downfield region in the complexes with compared to those of the free ligand. This downfield shift might be due to the donation of electron density from ring to $\mathrm{Sn}$ (IV) The allyl group $\left(-\mathrm{CH}_{2}-\mathrm{CH}=\mathrm{CH}_{2}\right)$ inside the aromatic ring exhibit three signals at the region $5.98-3.70 \mathrm{ppm}$ as multiplet and doublet. However, methyl protons of both methyltin(IV) (2) and dimethyltin(IV) (5) complexes showed a singlet at $1.10-1.07 \mathrm{ppm}$. The ${ }^{2} J$ $\left({ }^{119} \mathrm{Sn},{ }^{1} \mathrm{H}\right)$ coupling constant of complexes $\mathbf{2}$ and $\mathbf{5}$ are 72.4 and $76.3 \mathrm{~Hz}$ in agreement with five-coordinate tin(IV) centre. ${ }^{41}$ The calculated C9-Sn1-C10 angles by the Lockhart-Manders equations ${ }^{41}$ as $122.22^{\circ}$ and $126.41^{\circ}$ for complexes $\mathbf{2}$ and $\mathbf{5}$, respectively, support the proposed geometry.

The $\mathrm{C}=\mathrm{S}$ carbon signal is shifted to upfield region in the complexes compared with the free ligand, supported coordination through thiolate sulphur to tin(IV) atom. The chemical shift due to the $\mathrm{C}=\mathrm{N}$ is observed at downfield (168.72-161.75 ppm) in the complexes compared with the ligand $(152.81 \mathrm{ppm})$, clearly indicate the coordination of the azomethine nitrogen to
tin(IV). The carbon signal due to aromatic ring carbons at $136.14-120.28 \mathrm{ppm}$ in free ligand is shifted slightly downfield upon complexation. These observations also support coordination through phenolic oxygen to tin(IV) atom. The chemical shifts due to carbons in allyl group $\left(-\mathrm{CH}_{2}-\mathrm{CH}=\mathrm{CH}_{2}\right)$ and $\left(-\mathrm{OCH}_{3}\right)$ did not change upon complexation. The signals due to butyl carbon in complex $\mathbf{3}$ bonded to tin (Bu-Sn) appeared at 38.01-22.65 ppm. The value of the coupling constant ${ }^{1} J\left[{ }^{119} \mathrm{Sn},{ }^{13} \mathrm{C}\right]$ for complex 5 is $531.82 \mathrm{~Hz}$ which consistent with five-coordinate geometry around tin. ${ }^{42}$ The determination of $\mathrm{C}-\mathrm{Sn}-\mathrm{C}$ angle using the LockhartManders equation ${ }^{41} \theta(\mathrm{C}-\mathrm{Sn}-\mathrm{C})=\left[\left|{ }^{1} J\left({ }^{13} \mathrm{C}-{ }^{119} \mathrm{Sn}\right)\right|+\right.$ $875] / 11.4$ provided $\mathrm{C}-\mathrm{Sn}-\mathrm{C}$ angle of $123.4^{\circ}$ for complex 5. The observed value of $\mathrm{C}-\mathrm{Sn}-\mathrm{C}$ angle corresponds with the $\mathrm{C}_{\text {methyl }}-\mathrm{Sn}-\mathrm{C}_{\text {methyl }}$ angle obtained from $\mathrm{X}$-ray crystal analysis of dimethyltin(IV) complex $\mathbf{5}$.

The ${ }^{119}$ Sn NMR spectra of complexes (2-5) showed a sharp single resonance supported that only one single species is present. The ${ }^{119} \mathrm{Sn}$ NMR resonances were found to be in the range of -154.48 to $-171.35 \mathrm{ppm}$ for all complexes (2-5). The occurrences of chemical shift values for all complexes in this region suggested that five coordination environment around the central $\mathrm{Sn}(\mathrm{IV})$ atom. ${ }^{43,44}$

\subsection{Crystal structure of $\left[\mathrm{Me}_{2} \operatorname{Sn}(L)\right](5)$}

Yellow crystals suitable for X-ray diffraction analysis of the $\left[\mathrm{Me}_{2} \mathrm{Sn}(\mathrm{L})\right](5)$ were obtained by slow evaporation of methanol at room temperature. The molecular structure of $\left[\mathrm{Me}_{2} \mathrm{Sn}(\mathrm{L})\right]$ (5) along with the atomic numbering scheme and its packing in the crystal lattice are given in figures 2 and 3, respectively. Summary of crystal data and structure refinement results are given in table 1 . Important bond lengths $(\AA)$ and angles $\left(^{\circ}\right)$ are compiled in table 2 .

The compound crystallizes into monoclinic crystal system with a space group of $P 2_{1} / \mathrm{c}$. The molecular structure of complex 5 revealed that the ligand $\left(\mathrm{H}_{2} \mathrm{~L}\right)$ is coordinated to central tin(IV) atom through phenolic oxygen, azomethine nitrogen and thiolate sulphur atoms. The $\mathrm{Sn}(\mathrm{IV})$ is penta-coordinated and adopts a distorted trigonal bipyramidal geometry, with the oxygen and thiol sulphur atoms occupying axial positions while azomethine nitrogen atom and two methyl groups occupy the equatorial position. The two methyl groups and azomethine nitrogen are equatorial sites having angles $\mathrm{C} 9-\mathrm{Sn} 1-\mathrm{C} 10=128.20(6)^{\circ} \mathrm{C} 9-\mathrm{Sn} 1-\mathrm{N} 1$ $=103.24(5)^{\circ}$ and $\mathrm{N} 1-\mathrm{Sn} 1-\mathrm{C} 10=128.47(6)^{\circ}$. The sum of bond angles between $\mathrm{Sn}$ atom and equatorial atoms is $360^{\circ}$ indicating that they are completely coplanar with the $\mathrm{Sn}$ atom lying in the plane. The phenolic oxygen 


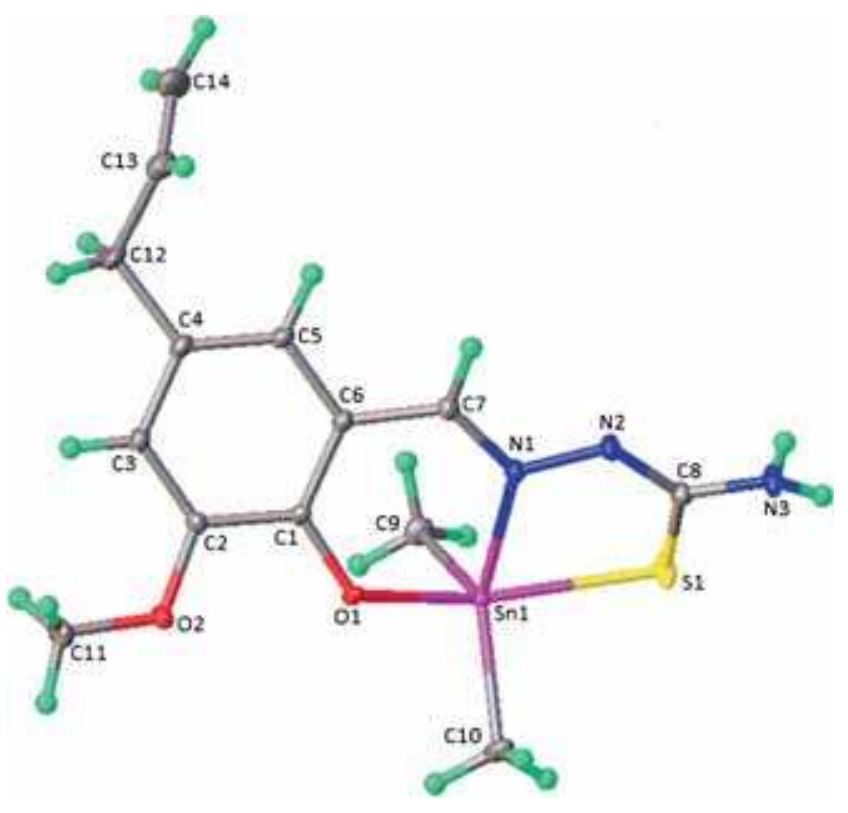

Figure 2. Molecular structure of $\left[\mathrm{Me}_{2} \mathrm{Sn}(\mathrm{L})\right](5)$ showing displacement ellipsoids at the $50 \%$ probability level.

(O1) and thiolate sulphur (S1) atoms bonded with Sn1 have axial positions $\mathrm{O} 1-\mathrm{Sn} 1-\mathrm{S} 1$ angle of $151.41(3)^{\circ}$. The distortion from trigonal bipyramidal geometry is evident from the bond angle O1-Sn1-N1 79.63(4) ${ }^{\circ}$ and $\mathrm{N} 1-\mathrm{Sn} 1-\mathrm{S} 175.95(3)^{\circ}$ as the sum of bond angles is $155.58^{\circ}$ significantly deviated from $180^{\circ}$. Furthermore, the bond angle of $\mathrm{N} 1-\mathrm{Sn} 1-\mathrm{C} 10$ is $128.47(6)^{\circ}$ which

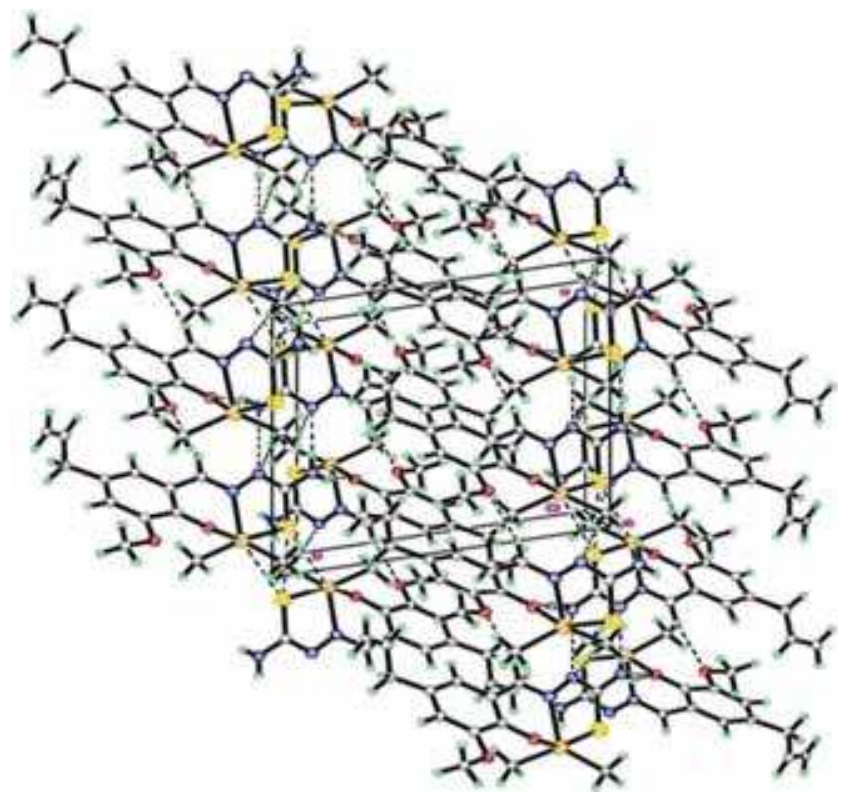

Figure 3. The packing diagram of $\left[\mathrm{Me}_{2} \mathrm{Sn}(\mathrm{L})\right]$ (5) in the crystal lattice, viewed along the $a$ axis. is smaller than $180^{\circ}$. Most probably, the distortion is owing to the participation of the N1 atom in five member chelate rings and also large covalent radius of $\mathrm{Sn}(\mathrm{IV})$. The C9-Sn1-C10 angle $\left(128.20(6)^{\circ}\right)$ is slightly larger than $120^{\circ}$ indicating that the two methyl groups also contribute for deviation. The deviation from the ideal trigonal bipyramidal geometry can be assigned from stretch exploited by the non-planar five member (Sn1-S1-C8-N2-N1) and six member (Sn1-O1C1-C6-C7-N1) chelate rings upon complexation. The bond angles between the planes of the two rings are C10-Sn1-C9 $\left(128.20^{\circ}\right), \mathrm{C} 10-\mathrm{Sn} 1-\mathrm{N} 1\left(128.47^{\circ}\right)$ and C9-Sn1-N1 $\left(103.24^{\circ}\right)$ for C10, C9 and N1 placed at the three edges of the trigonal plane which is evidence for the distortion from the perfect TBP geometry. The Sn1S1 [2.5497(4) A] and Sn1-N1 [(2.2212(11) A] bond lengths are similar to those of other five-coordinate distorted trigonal tin complexes of tridentate ONS donors ligand. ${ }^{45,46}$ The Sn1-O1 bond distance [2.1181(10) $\left.\mathrm{A}\right]$ is almost similar to the covalent radii of $\mathrm{Sn}-\mathrm{O}(2.10 \AA)$, considering significant bonding interaction and comparable with reported article. ${ }^{47}$ The Sn1-N1 distance $[2.2212(11) \AA]$ is a little longer than the sum of Sn$\mathrm{N}$ covalent radii $(2.15 \AA),{ }^{48}$ considered as strong bonding and consistence with those reported literature. ${ }^{49}$ The bond distances of Sn1-C9 (2.1243 $\AA$ ) and Sn1-C10 $(2.1200 \AA)$ are comparable with those found in other reported organotin(IV) compounds. ${ }^{50,51}$ The packing of the molecules in the crystal structure is stabilized by intra and intermolecular hydrogen bonding interactions. The most important feature of the crystal packing is the formation of $\mathrm{N} 3 \mathrm{H} \cdots \mathrm{N} 2, \mathrm{~N} 3 \mathrm{H} \ldots \mathrm{O} 1$ and $\mathrm{C} 10-\mathrm{H} \cdots \mathrm{N} 2$ hydrogen bonds. Centrosymmetric dimers in the crystal packing are conciliated by N-H....S hydrogen bonds.

\subsection{Antibacterial Activity}

Antibacterial studies of all compounds were carried out in vitro against Staphylococcus aureus, Escherichia coli, Enterobacter aerogenes and Salmonella typhi. In this experiments, inhibition zone in millimetre units were presented in table 3 . From table 3 , it can be concluded that all compounds showed high activity against different bacterial strains but slightly low activity with compared to standard drug (Doxycycline). The ligand showed moderate activity might be due to the presence of $\mathrm{OH} / \mathrm{NH}$ groups within the parent ligand. ${ }^{52}$ Comparison of the antibacterial activity of the free ligand and its organotin(IV) complexes showed that ligand $\left(\mathrm{H}_{2} \mathrm{~L}\right)$ exhibits less activity. The increase in activity of the complexes might be due to the chelation of ligand with tin(IV) leading to electron delocalization and 
Table 1. Crystal data and structure refinement parameters for $\left[\mathrm{Me}_{2} \mathrm{Sn}\right.$ (L)] (5).

\begin{tabular}{|c|c|}
\hline Compound & {$\left[\mathrm{Me}_{2} \mathrm{Sn}(\mathrm{L})\right](\mathbf{5})$} \\
\hline Empirical formula & $\mathrm{C}_{14} \mathrm{H}_{19} \mathrm{~N}_{3} \mathrm{O}_{2} \mathrm{SSn}$ \\
\hline Formula weight & 412.07 \\
\hline Temperature (K) & 100 \\
\hline Wavelength $(\AA)$ & 0.71073 \\
\hline Crystal system & Monoclinic \\
\hline Space group & $P 2_{1} / \mathrm{c}$ \\
\hline \multicolumn{2}{|l|}{ Unit cell dimensions } \\
\hline a $(\AA)$ & $11.5023(7)$ \\
\hline b $(\AA)$ & $13.6747(8)$ \\
\hline$c(\AA)$ & $11.1597(7)$ \\
\hline$\alpha\left(^{\circ}\right)$ & 90 \\
\hline$\beta\left(^{\circ}\right)$ & $100.3584(8)$ \\
\hline$\gamma\left({ }^{\circ}\right)$ & 90 \\
\hline Volume $\left(\AA^{3}\right)$ & $1726.71(18)$ \\
\hline $\mathrm{Z}$ & 4 \\
\hline Calculated density $\left(\mathrm{mg} / \mathrm{m}^{3}\right)$ & 1.585 \\
\hline Radiation type $\lambda(\AA)$ & $\mathrm{M}_{0} \mathrm{~K} / \mathrm{a}$ \\
\hline $\mathrm{F}(000)$ & 824 \\
\hline Crystal size (mm) & $0.14 \times 0.40 \times 0.47$ \\
\hline Crystal colour & Orange \\
\hline Scan range $\theta\left(^{\circ}\right)$ & $2.78-30.22$ \\
\hline Absorption coefficient $(\mu)\left(\mathrm{mm}^{-1}\right)$ & 1.607 \\
\hline Max. and min. transm & 0.805 and 0.522 \\
\hline Goodness-of-fit on $\mathrm{F}^{2}$ & 1.142 \\
\hline Data/Restrains/ parameters & $5076 / 0 / 201$ \\
\hline Final $\mathrm{R}$ indices $[\mathrm{I}>2 \sigma(\mathrm{I})]$ & $\mathrm{R}_{1}=0.0183, \mathrm{wR}_{2}=0.0191$ \\
\hline $\mathrm{R}$ indices (all data) & $\mathrm{R}_{1}=0.0551, \mathrm{wR}_{2}=0.0558$ \\
\hline
\end{tabular}

potent diffusion of the metal complexes into bacterial cell. ${ }^{53,54}$ Based on the results, dimethyltin(IV) complex 5 exhibits highest antibacterial activity with inhibition zone rangeing $29.4-27.5 \mathrm{~mm}$. Phenyltin(IV) complex 4 exhibits significantly better activity with inhibition zones in the range of $27.5-26.4 \mathrm{~mm}$ against all bacterial strains $\mathrm{MeSnCl}(\mathrm{L})$ (2) complex exhibits higher activity than $\mathrm{BuSnCl}(\mathrm{L})$ (3) complex against all bacteria. Therefore, nature of the organo groups (phenyl, methyl and butyl) attached to the tin(IV) centre might

Table 2. Selected bond lengths $(\AA)$ and angles $\left({ }^{\circ}\right)$ of $\left[\mathrm{Me}_{2} \mathrm{Sn}(\mathrm{L})\right](\mathbf{5})$.

\begin{tabular}{lccc}
\hline Bond lengths $(\AA)$ & & & \\
Sn1-S1 & $2.5495(5)$ & Sn1-O1 & $2.1181(10)$ \\
Sn1-N1 & $2.2212(11)$ & Sn1-C9 & $2.1243(16)$ \\
Sn1-C10 & $2.1200(16)$ & S1-C8 & $1.7417(14)$ \\
O1-C1 & $1.3288(16)$ & O2-C2 & $1.3704(18)$ \\
O2-C11 & $1.426(2)$ & N1-N2 & $1.3837(17)$ \\
N1-C7 & $1.3038(18)$ & N2-C8 & $1.3211(18)$ \\
N3-C8 & $1.336(2)$ & C1-C2 & $1.4248(19)$ \\
& & & \\
Bond angles $\left(^{\circ}\right)$ & & & \\
S1-Sn1-O1 & $151.41(3)$ & S1-Sn1-N1 & $75.96(3)$ \\
S1-Sn1-C9 & $102.49(5)$ & S1-Sn1-C10 & $93.68(4)$ \\
O1-Sn1-N1 & $79.63(4)$ & O1-Sn1-C9 & $97.36(5)$ \\
O1-Sn1-C10 & $89.93(5)$ & N1-Sn1-C9 & $103.24(5)$ \\
N1-Sn1-C10 & $128.47(5)$ & C9-Sn1-C10 & $128.20(6)$ \\
Sn1-S1-C8 & $96.24(5)$ & Sn1-O1-C1 & $123.08(8)$ \\
Sn1-N1-N2 & $122.43(8)$ & Sn1-N1-C7 & $122.48(10)$ \\
N2-N1-C7 & $114.79(11)$ & N1-N2-C8 & $115.94(11)$ \\
\end{tabular}


Table 3. Antibacterial activity ${ }^{\mathrm{a}}$ of ligand (1) and its organotin(IV) complexes (2-5) (inhibition zone in $\mathrm{mm}$ ).

\begin{tabular}{lcccc}
\hline & \multicolumn{4}{c}{ Bacterium } \\
\cline { 2 - 5 } Compounds & S. aureus & E. coli & E. aerogenes & S. typhi \\
\hline $\mathbf{H}_{\mathbf{2}} \mathbf{L}(\mathbf{1})$ & 14.2 & 12.4 & - & 11.8 \\
$\mathbf{2}$ & 23.8 & 24.1 & 25.1 & 24.3 \\
$\mathbf{3}$ & 23.2 & 20.8 & 22.9 & 21.2 \\
$\mathbf{4}$ & 26.4 & 25.7 & 26.1 & 27.5 \\
$\mathbf{5}$ & 27.8 & 28.9 & 27.5 & 29.4 \\
$\mathbf{R}$ & 31.6 & 33.4 & 32.5 & 33.1 \\
\hline
\end{tabular}

${ }^{\mathrm{a} C}$ Concentration used: $2 \mathrm{mg} / \mathrm{mL}$ of DMSO, $\mathrm{R}=$ standard drug: Doxycycline, dash indicate inactivity.

play an important role in growth inhibitory activity. The organotin(IV) derivatives remarkably inhibit gramnegative/gram-positive bacterial growth. The enhanced antibacterial activity of organotin(IV) derivatives compared to the parent ligand is most possibly due to the reduction in the polarity of the tin(IV) atom upon coordination with the ligand. The antibacterial activities of the studied organotin(IV) compounds are comparable with other reported organotin complexes. ${ }^{55-57}$ Hence, organotin(IV) complexes studied in this work may be good candidates to be used as new antibacterial agents. Detailed studies in this research field will be investigated in future biological applications.

\section{Conclusion}

Four new organotin(IV) complexes of 5-allyl-2-hydroxy-3-methoxybenzaldehyde-4-thiosemicarbazone have been synthesized and their proposed structures are supported by various physico-chemical methods. From the single crystal X-ray molecular structure of complex $\mathbf{5}$, it can be concluded that ONS-donor thiosemicarbazone ligand $\left(\mathrm{H}_{2} \mathrm{~L}\right)$ is completely deprotonated and coordinated to the tin(IV) moiety via phenolic oxygen, azomethine nitrogen and thiolate sulphur atoms. All the synthesized complexes have shown pronounced biological activities. These organotin(IV) complexes have good antibacterial activity and may be designed as potential drugs in the pharmaceutical field in future

\section{Supplementary Information}

UV-Visible, FT-IR and multinuclear NMR $\left({ }^{1} \mathrm{H},{ }^{13} \mathrm{C}\right.$, and ${ }^{119} \mathrm{Sn}$ ) spectra of the ligand and its complexes (figures S1-S9) are available at www.ias.ac.in/chemsci. CCDC reference number 1054928 contains the supplementary crystallographic data for $\left[\mathrm{Me}_{2} \mathrm{Sn}(\mathrm{L})\right](\mathbf{5})$. This data can be obtained free of charge from the
Cambridge Crystallographic data center via www.ccdc. ac.uk/data_request/cif or from the Cambridge Crystallographic data center, 12 Union Road, Cambridge CB2 1EZ, UK; fax: (+44) 1223-336-033; or e-mail: deposit@ccdc.cam.ac.uk.

\section{Acknowledgment}

R.A.H. thanks Universiti Sains Malaysia (USM) for the Research University (RU) Grant 1001/PKIMIA/ 811217. M.A.S. thanks USM and Third World Academy of Sciences (TWAS) for a post-doctoral research fellowship. We also thank the Bangladesh Petroleum Exploration and Production Co. Ltd. (BAPEX), Bangladesh, for the study leave to M. A. Salam.

\section{References}

1. Campbell M J M 1975 Coord. Chem. Rev. 15279

2. Tojal J G, Orad A, Diaz A A, Serra J L, Urtiaga M K, Arriortua M I and Rojo T 2001 J. Inorg. Biochem. 84 271

3. El-Ayaan U, Youssef M M S and Al-Shihry 2009 J. Mol. Struct. 936213

4. Lukmantara A Y, Kalinowski D S, Kumar N and Richardson D R 2013 Bioorg. Med. Chem. Lett. 23967

5. Walcourt A, Loyevsky M, Lovejoy D B, Gordeuk V R, Richardson and Des R 2004 Int. J. Biochem. Cell Biol. 36401

6. Serda M D, Kalinowski S, Wilczkiewicz A M, Musiol R, Szurko A, Ratuszna A, Pantarat N, Kovacevic Z, Merlot A M, Richardson D R and Polanski R 2012 J. Bioorg. Med. Chem. Lett. 225527

7. Mendes I C, Moreira J P, Speziali N L, Mangrich A S, Takahashi J A and Beraldo H 2006 J. Braz. Chem. Soc. 171571

8. Silva J G, Azzolini L S, Wardell S M S V, Wardell J L and Beraldo H 2009 Polyhedron 282301

9. Khoo L E, Xu Y, Goh N K, Chia L S and Koh L L 1997 Polyhedron 16573

10. Dakternieks D, Basu-Baul T S, Dutta S and Tiekink E R T 1998 Organometallics 173058

11. Teoh S G, Ang S H, Fun H K and Ong C W 1999 J. Organomet. Chem. $\mathbf{5 8 0} 17$ 
12. Gielen M, Biesemans M and Willen R 2005 Appl. Organomet. Chem. 19440

13. Chaudhary P, Swami M, Sharma D K and Singh R V 2009 Appl. Organomet. Chem. 23140

14. Zubita J A and Zukerman J J 1987 Inorg. Chem. 24251

15. Rebolledo A P, Vieites M, Gambino D, Piro O E, Castellano E E, Zani C L, Souza-Fagundes E M, Teixeira L R, Batista A A and Beraldo H 2005 J. Inorg. Biochem. 99698

16. West D X, Bain G A, Butcher R J, Jasinski J P, Li Y, Pozdniakiv R Y, Valdes- Martinez J, Toscano R A and Hernandes-Ortega S 1996 Polyhedron 15665

17. Maurya M R, Kumar A, Abid M and Azam A 2006 Inorg. Chim. Acta 3592439

18. Alomar K, Khan M A, Allain M and Bouet G 2009 Polyhedron 281273

19. Vieites M, Otero L and Santos D 2009 J. Inorg. Biochem. 103411

20. de Sousa G F, Francisco R H P, Gambardella M T d P, Santos R H d A and Abras A 2001 J. Braz. Chem. Soc. 12722

21. Hussein M A, Guan T S, Haque R A, Ahamed M B K and Majid A M S A 2015 Polyhedron 8593

22. Hussein M A, Guan T S, Haque R A, Ahamed M B K and Abdul Majid A M S 2014 J. Coord. Chem. 67714

23. Gómez-Saiz P, García-Tojal J, Maestro M, Mahía J, Lezama L and Rojo T 2003 Eur. J. Inorg. Chem. 2003 2123

24. López-Torres E, Mendiola M A, Pastor C J and Procopio J R 2003 Eur. J. Inorg. Chem. 20032711

25. Casas J S, García-Tasende M S and Sordo J 2000 Coordination Chemistry Reviews 209197

26. Yang Z Y, Yang R D and Yu K B 1996 Polyhedron 15 3771

27. Garcia-Zarracino R, Ramos-Quinones $\mathrm{J}$ and Höpfl $\mathrm{H}$ 2003 Inorg. Chem. 423835

28. Tsangaris J M and Williams D R 1992 Appl. Organomet. Chem. 63

29. Sheldrick G M, SHELXTL Version 5.1 Software Reference Manual 1997 Bruker AXS Inc, Madison, Wisconsin, USA

30. Rahman A, Choudry M A and Thomsen M I W J 2001 In Bioassay Techniques for Drug Development (Harwood Academic Publishers: The Netherlands)

31. Maurya R M, Jayaswal M N, Puranik V G, Chakrabarti P, Gopinathan S and Gopinathan C 1997 Polyhedron 16 3977

32. Silverstein R M, Bassler G C and Morrill T C 1981 In Spectrometric Identification of Organic Compounds 4th ed. (Wiley: New York)

33. Singh S, Bharti N, Naqvi F and Azam A 2004 Eur. J. Med. Chem. 39459

34. Costa F F, Rebolledo A P, Matencio T, Calado H D R, Ardisson J D, Cortes M E, Rodrigues B L and Beraldo H 2005 J. Coord. Chem. 581307
35. Mendes I C, Moreira J P, Mangrich A S, Balena S P, Rodrigues B L and Beraldo H 2007 Polyhedron 26 3263

36. Rajan O A and Chakravarthy A 1981 Inorg. Chem. 20 660

37. Sedaghat T and Shokohi-Pour Z 2009 J. Coord. Chem. 623837

38. Saraswat B S, Srivastava G and Mehrotra R C 1979 J. Organomet. Chem. 164153

39. Teoh S G, Teo S B, Yeap G Y and Declercq J P 1991 Polyhedron 102683

40. Mesubi M A and Enemo R E 1982 Spectrochim. Acta A 38599

41. Lockhart T P and Manders W F 1986 Inorg. Chem. 25 892

42. Nath M, Saini P K and Kumar A 2010 J. Organomet. Chem. 6951353

43. Yin H D and Chen S W 2006 Inorg. Chim. Acta 359 3330

44. Wrackmeyer B 1985 Annual Reports on NMR Spectroscopy 1673

45. Chee D N A, Affan M A, Ahmad F B, Asaruddin M R, Sam N, Salam M A, Ismail A and Tan S H 2011 J. Coord. Chemi. 644191

46. de Sousaa G F, Franciscob R H P, Gambardellab M T P, Santosb R H deA and Abras A 2001 Braz. Chem. Soc. 12722

47. Labisbal E, Rodriguez L, Sousa-Pedrares A, Alonso M, Vizoso A, Romero J, Garcia-Vazquez A and Sousa A 2006 J. Organomet. Chem. 6911321

48. Purcell K F and Kotz J C 1980 In An Introduction to Inorganic Chemistry (Saunders College Publishing: Orlando, USA)

49. Pettinari C, Marchetti F, Pettinari R, Martini D, Drozdov A and Troyanov S 2001 Inorg. Chim. Acta 325103

50. Lopez-Torres E, Mendiola M A, Pastor C J and Procopio J R 2003 Eur. J. Inorg. Chem. 20032711

51. Casas J S, Castineiras A, Rodríguez-Arguelles M C, Sanchez A, Sordo J, Vazquez- Lopez A and VazquezLopez E M 2000 J. Chem. Soc., Dalton Trans. 2000 2267

52. Rehman W, Baloch M K and Badshah A 2008 Eur. J. Med. Chem. 432380

53. Chohan Z H, Hassan M U I, Khan K M and Supuran C T 2005 J. Enzyme Inhib. Med. Chem. 20183

54. Dharmaraj N, Vishwanathamurthi V and Natarajan K 2001 Transition Met. Chem. 26105

55. Ming-Xue L, Dong Z, Li-Zhi Z, Jing-Yang N and BianSheng J 2011 J. Organomet. Chem. 696852

56. Mendes I C, Moreira J P, Ardisson J D, dos Santos R G, da Silva P R O, Garcia I, Castiñeiras A and Beraldo H 2008 Eur. J. Med. Chem. 431454

57. Shujah S, Rehman Z, Muhammada N, Ali S, Khalid $\mathrm{N}$ and Tahir M N 2011 J. Organomet. Chem. 696 2772 